\title{
Two new species of the genus Corydoras (Ostariophysi: Siluriformes: Callichthyidae) from northwestern Argentina, and redescription of $C$. micracanthus Regan, 1912
}

\author{
Pablo A. CALVIÑO \& Felipe ALONSO
}

\begin{abstract}
KCA, Grupo de Estudio del Killi Club Argentino, Independencia 443, Villa Ballester CP 1653, Buenos Aires, Argentina. e-mail: pablocalvin@yahoo.com.ar; felipealonso@gmail.com
\end{abstract}

\begin{abstract}
The group herein denominated as the Corydoras micracanthus species-group is supported by presenting dorsal and pectoral spines length reduced; caudal fin slightly emarginated; low body depth; parieto-supraoccipital process and nuchal plate not in contact and small eyes for the genus. It comprises Corydoras micracanthus, herein redescribed, and two new species described in the present paper, all from northwestern Argentina. Corydoras gladysae, a new species from the Calchaquí river, is distinguished from other species of the genus by the caudal-fin shape, slightly emarginated and by presenting the shortest dorsal and pectoral spines length (mean $=9.2 \%$ and $14.8 \%$ of SL, respectively). Corydoras petracinii, a new species from the Las Costas river, is distinguished from its congeners by the following combination of characters: dorsal spine short $($ mean $=16.6 \%$ of SL), pectoral spine short (mean $=18.3 \%$ of SL), body moderately elongate (body depth $29.5 \%$ SL mean), caudal fin slightly forked and trunk flanks with 5-7 subsquare differenced blotches in the middle region. Corydoras micracanthus, from the Mojotoro river basin, is defined by its higher number of dorsolateral body plates (24-26) and trunk color pattern, presenting 4 to 6 subsquare blotches well differentiated in the flanks. The inclusion of these species into the genus Corydoras is discussed.
\end{abstract}

Key words: Systematics, Corydoras micracanthus, Corydoras petracinii, Corydoras gladysae, Salta, South America.

Resumen: Dos nuevas especies del género Corydoras (Ostariophysi: Siluriformes: Callichthyidae) del noroeste de Argentina, y la redescripción de $C$. microcanthus Regan, 1912. El grupo aquí denominado como grupo de especies Corydoras micracanthus es sustentado por presentar una longitud reducida de las espinas dorsal y pectoral, aleta caudal suavemente emarginada, cuerpo bajo, extremo del proceso parietosupraoccipital sin contacto con la placa predorsal y ojos pequeños para el género. Este grupo comprende Corydoras micracanthus aquí redescripta, y dos especies nuevas descriptas en el presente trabajo, todas endémicas del noroeste argentino. Corydoras gladysae, nueva especie, procedente del río Calchaquí, se distingue de sus congéneres por la forma de la aleta caudal ligeramente emarginada y por presentar la longitud de las espinas dorsal y pectoral muy corta (media $=9,2 \%$ y 14,8 \% de LE, respectivamente). Corydoras petracinii, nueva especie, procedente del río Las Costas, se distingue de sus congéneres por la siguiente combinación de caracteres: espina dorsal corta (media 16,6 \% LE), espina pectoral corta (media 18,3\% LE), cuerpo moderadamente alargado (altura del cuerpo media 29,5\% LE), aleta caudal suavemente bifurcada y un patrón de coloración con 5-7 manchas subcuadradas en la región media del cuerpo. Corydoras micracanthus, procedente de la cuenca del río Mojotoro, es definida por el mayor número de escudos superiores (24-26) y por el patrón de color del cuerpo que presenta 4 a 6 manchas subcuadradas bien diferenciadas en los flancos. Se discute la inclusión de estas especies dentro del género Corydoras.

Palabras clave: Sistemática, Corydoras micracanthus, Corydoras petracinii, Corydoras gladysae, Salta, Sudamérica.

\section{INTRODUCTION}

Corydoras Lacépède, is a genus of the Callichtyidae family widely distributed in CisAndean South America (Britto \& Lima, 2003), being found from the eastern Andes to the Atlantic Coast, and from Trinidad (Reis, 1998) to the northwestern drainages of the southern mountain range from Ventania system, Buenos Aires, Argentina (Ringuelet et al., 1967). It also has been found in north Patagonia (Baigún et al., 2002). This fish inhabits a wide variety of envi- ronments such as shallow marginal areas, flooded zones and small streams (Britto \& Lima, 2003), channels and lagoons. Currently, the genus includes 150 valid species, being one of the richest genus of Neotropical fishes in regards to the amount of species. Only 10 of them have been registered as valid for Argentina: Corydoras aeneus (Gill, 1858), C. aurofrenatus Eigenmann \& Kennedy 1903; C. carlae Nijssen \& Isbrücker, 1983; C. ellisae Gosline, 1940; C. hastatus Eigenmann \& Eigenmann, 1888; C. longipinnis Knaack, 2007; C. micracanthus Regan, 1912; C. 
paleatus (Jenyns, 1842), C. polystictus Regan, 1912 and C. undulatus Regan, 1912 (López et al., 2003; Knaack, 2007).

Unlike most catfish that have nocturnal habits, the Corydoras species has a diurnal activity (Nijssen \& Isbrücker, 1980, 1986; Staruss, 1985) and is one of the more known genera by the fishkeepers since most of the species of this genus are considered ornamental fish (Burguess \& Quinn, 1992).

Corydoras micracanthus described by Regan (1912) on the basis of specimens obtained in the province of Salta, Argentina, was only known by the original description and it has not been reviewed again until today possibly because its presence in aquariums and the ichthyological collections is very poor; nevertheless Nijssen \& Isbrücker (1980) designated a lectotype and paparelctotypes without making a mention of distinguishing features or redescription.

On the basis of new collections made in the Salta province, in northwestern Argentina, two new species of genus Corydoras are described in this article and C. micracanthus is redescribed. These three species are proposed as a group denominated here «C. micracanthus group» characterized by dorsal and pectoral spines short; caudal fin slightly emarginated; body depth low; supraoccipital and nuchal plate not in contact and small eyes for the genus. Additional data of ecology, biology and aquarium behavior are given.

\section{MATERIALS AND METHODS}

Measurements were taken with a digital caliper $( \pm 0.1 \mathrm{~mm})$ from point to point. To take the morphometric and meristic data we followed Reis (1997) with modifications of Britto (2000). The following additional data was also taken: longer dorsal soft ray. In the description, the frequency of each count (mode) is provided between parenthesis and the value corresponding to holotype is given with an asterisk. The holotypes of the species herein described, and part of the comparative material used, were maintained in aquariums during 6 months before its fixation in formaldehyde, with the intention of enriching the present study with behavior data, and photographs of live specimens. The type material is deposited in Museo Argentino de Ciencias Naturales «Bernardino Rivadavia», Buenos Aires, Argentina (MACN) and Museo de Ciencias Naturales de Salta, Argentina (MCNI).

The abbreviations used are: HL: head length; SL: standard length; SD: standard deviation; m.a.s.l.: meters above sea level.

\section{Comparative material}

Corydoras aeneus: MACN 8686, 3 ex., 23.9$44.2 \mathrm{~mm}$ SL; Saenz Peña, (S 26 $51^{\circ} \mathrm{S}-\mathrm{W} 60^{\circ}$ 26'), Chaco, Argentina. Coll. C. Baigún, 21 Jul. 2004. Corydoras cf. aeneus: MACN 4810, 4 ex., 26.0-28.0 mm SL; charcos alrededores de la ciudad de Resistencia, Chaco, Argentina. Coll. I. Apostol, Aug. 1961. Corydoras hastatus: MACN 6974, 6 ex., 9.2 - 22.2 mm SL; Guayquiraró river, Corrientes, Argentina. Coll. H. Castello, 15 Aug. 1974. MACN 4773, 10 ex., 10.7-17.1 mm SL; charcos y lagunas en San Cosme, Corrientes, Argentina. Coll. I. Apostol, Aug. 1961. Corydoras ellisae: MACN 8268, 14 ex., 31.3-42.5 mm SL; Santa Lucía river, Corrientes, Argentina. Coll. Fernández Santos, Oct. 1973. Corydoras ef. paleatus: MACN 9237, 9 specimens; small stream 200 meters from its ending into the San Lorenzo river (S 24 $47^{\prime} 08^{\prime \prime}$ - W 65 $28^{\circ} 10^{\prime \prime}$; Altitude: 1222 m.a.s.l.), Finca Las Costas, Salta Capital, Argentina. Coll. F. Alonso and J. Traine, January of 2007. Corydoras cf. paleatus: MCNI 049, 7 ex., 41.6-55.7 mm SL; Finca Las Costas, Salta Capital, Argentina. Coll. Gladys Monasterio de Gonzo, 4 Oct. 1993. MACN 7905, 16 ex., 33.0-64.2 mm SL; canales de riego, Neuquén, Argentina. Coll. E. García, Jun. 1993. Corydoras aff. paleatus MACN 4069, 8 ex., 17.9-35.7 mm SL; Uruguay river, Concepción del Uruguay, Entre Ríos, Argentina. Coll. A. Mani, E. Siccardi, A. Gneri, Dec. 30, 1947. Corydoras paleatus: MACN 2554, 5 ex., 28.2-42.9 mm SL; de la Plata river in Ensenada, Buenos Aires, Argentina. Coll. A. Pozzi, 1937. MACN 8633, 2 ex., 34.9-37.0 mm SL; Negro river, between Gral. Roca and Allen, Río Negro, Argentina. Coll. December. 2002. MACN 9061, 20 ex., 15.2-33.8 mm SL; Manantiales creek (S 35 $02^{\prime}$ $34^{\prime \prime}$ - W 58 19' 37"), Buenos Aires, Argentina. Coll. Ferriz, Bentos, Fernández y López, Ene. 2006. MACN 4914, 9 ex., 48.3-72.3 mm SL; Laguna Carué, Buenos Aires, Argentina. Coll. I. Apostol, July. 1962. Corydoras undulatus: MACN 8275, 3 ex., 31.2-35.2 mm SL; Nancay creek, Entre Ríos, Argentina. Coll. Fernández Santos y Castelli, May. 1974.

\section{SYSTEMATICS}

\section{Corydoras gladysae sp. nov.}

(Fig. 1)

Holotype. MACN 9232, $35.0 \mathrm{~mm} \mathrm{LE;}$ Calchaquí river, (S 25 2' 59" - W 66 6' 25"; Altitude: 2430 m.a.s.l.) Payogasta, Cachi Department, Salta province, Argentina. Coll. Felipe Alonso, January 2007. 


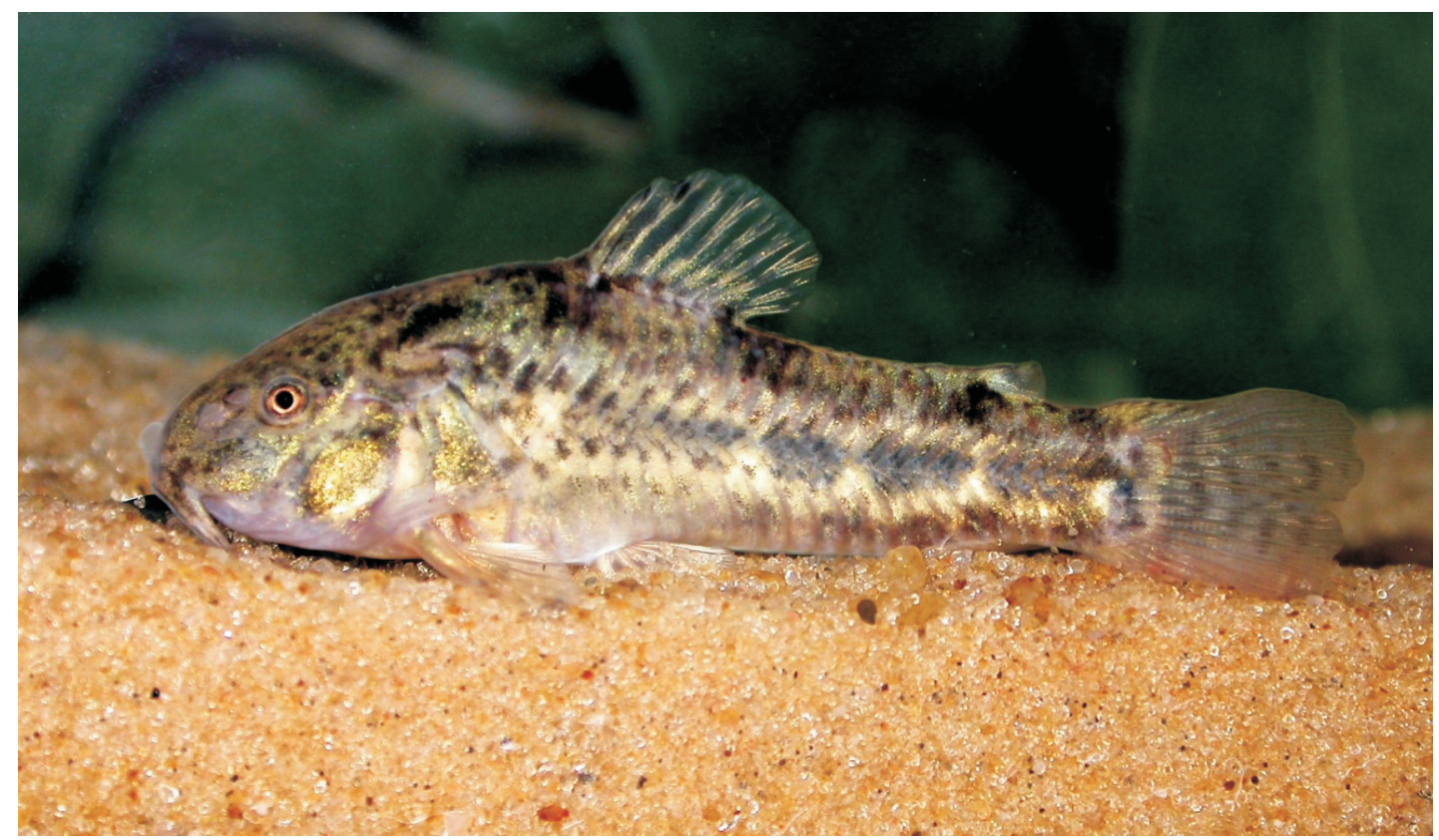

Fig. 1. Corydoras gladysae sp. n., MACN 9232, live holotype, 35.0 mm SL. Argentina, Salta province, Calchaquí river (S 252' 59" - W 66 6' 25"). Photo: P. Calviño.

Paratypes. MCNI 712, 4 specimens, 37.528.5 mm LE; Calchaquí river, Cachi Department, Salta province, Coll. Gonzo y Martínez, January 19, 2002. MCNI 913, 4 specimens, 37.5-27.6 mm SL; Calchaquí river, (S 25 $7^{\prime} 17^{\prime \prime}$ and W $66^{\circ} 9^{\prime}$ 35"; Altitude: 2325 m.a.s.l.) Cachi Department, Salta province, Argentina. Coll. Gonzo and Martínez, December 7, 2003.

Diagnosis. Corydoras gladysae is easily distinguished by presenting three unique features for the genus: 1) very short length of the ossified portion of dorsal spine [7.6-10.6\% SL (average $=9.2$ ) ] 2) very short length of the pectoral spines [ $11.9-17.4 \%$ SL (average $=14.8$ ) ] and 3) caudal fin shape, slightly emarginated.

In addition, Corydoras gladysae can be differentiated from other species of the genus by the following combination of features: $24-25$ dorsolateral body plates (mode $=25)$; $21-22$ ventrolateral body plates (mode $=22)$; small eye $(7.3-$ $12.5 \% \mathrm{HL}$ ) located dorso-laterally on head; dorsal fin rounded shaped; dorsal fin very low height in males and females (average $18.1 \% \mathrm{SL}$ ), body depth (29.0-35.7\% SL); posterior expansion of the parieto-supraoccipital process triangular and elongated; separation of the predorsal plate by one or two dorsolateral body plates; trunk and head covered by a thin skin, with tiny dispersed odontodes and caudal fin with four or five series of small dark brown blotches restricted to rays, forming poorly defined vertical stripe pattern.

Description. Morphometric data presented in Table 1. Body short, robust. Snout rounded, pointless. Head profile convex from the snout to eye; approximately straight from eye to parietosupraoccipital process. Profile of body straight or slightly convex from tip of parietosupraoccipital process to last dorsal-fin ray. Postdorsal-fin body profile slightly concave to adipose-fin spine; noticeably concave from this point to the caudal-fin base. Ventral profile of body slightly convex from isthmus to anal-fin origin. Profile concave from first anal-fin ray to caudalfin base. Body roughly cylindrical in cross section at pectoral girdle, gradually becoming more compressed toward caudal fin; maximum body width in humeral region.

Eye round, small for the genus, located dorsolaterally on head; orbit delimited dorsally by frontal and sphenotic, ventrally by infraorbitals; Anterior and posterior nares very close to each other. Anterior naris tubular. Posterior naris non tubular, very close to the orbit anterior margin, only separated by flap of skin. Mouth located ventrally. Maxillary barbel generally reach anteroventral limit of gill opening. One indivudual presents the left anterior maxillary barbel forked. Mental barbel very short. Small 
rounded papillae covering entire surface of all barbels, upper and lower lips. Supraoccipital process externally visible and predorsal plate exposed just in front of first dorsal-fin ray. Posterior expansion of supraoccipital process triangular and elongated, separated from nuchal plate by one or two dorsolateral body plates. Trunk and head covered by a thin skin, with dispersed tiny odontodes.

Dorsal fin shape rounded; its origin just on third dorsolateral body plate. Dorsal spine shorter than first seven dorsal fin rays. Dorsal fin rays I,7 or I,8; third and forth rays are the longest. Anterior border of dorsal spine smooth; posterior border with minute serrations. Adipose fin short with curved spine, approximately triangular in shape; the membrane base extends on 2 or 3 dorsolateral body plates, its origin separated from base of last dorsal-fin ray by 7 to 9 dorsolateral body plates. Anal fin ellipsoid or rounded, its origin located slightly anterior to adipose fin origin in most specimens; and at same distance in some. Anal-fin rays: i,5,i*(2), i,6(3), i,7(1), ii,3,i(1), ii,4(2). Pectoral fin approximately triangular with rounded margins; its origin located just posterior to gill opening. Ossified portion of pectoral spine shorter than firsts branched rays; its posterior border serrated; Pectoral fin reaches pelvic fins origin. Pectoral-fin rays: I,7 or I,8. Pelvic fin ellipsoid, its origin just below third ventrolateral body plates, at vertical through base of second branched dorsal-fin ray; it does not reach anal fin; base of pelvic fin ends just anterior to anus. Pelvic-fin rays: i,5; one specimen i,6. Caudal fin smoothly emarginated, almost truncated; posterior edge rounded. Principal caudal-fin rays: 13 (3), 14*(3), 15(3); upper procurrent caudal-fin rays: iv (3), v (3), vi*(3); lower procurrent caudal-fin rays: iv (3), v (3), $\mathrm{vi}^{*}(3)$.

Dorsolateral body plates: $24(6)$ to $25^{*}(3)$; ventrolateral body plates: $21(2)$ to $22 *(7)$; dorsolateral body plates along dorsal-fin base: 4 (1), 5(4), $6 *(2)$; dorsolateral body plates from adipose fin to caudal-fin base: $3 *(2), 4(6), 5(1)$.

Color in life. Ground color of head brown. Opercle dark brown with golden green reflections. Preopercular edge light brown to reddish. Ventral region of head light. Dark brown blotch between opercle and parieto-supraoccipital process. Barbel sometimes with little blotches, almost imperceptibles.

Ground color of trunk light brown with small dark brown blotches distributed on flanks and dorsal region. Large dark brown blotches over lateral line region on body plates sometimes grouped forming a wide discontinuous and irregular strip. Dorsal region presents three great dark blotches slightly distinguished form ground color; first blotch occupies the base of the dorsal fin first rays, second blotch appears at the posterior end of the dorsal fin; and third blotch in adipose fin base. Ventral surfaces of body yellowish white. Dorsal fin hyaline with dark anterior margin and points or small blotches to rays, sometimes forming one or two incomplete oblique stripe. Caudal fin with four or five series of small dark brown blotches restricted to rays, forming poorly defined vertical stripe pattern. Caudal fin membranes hyaline. Pelvic fin generally hyaline, eventually with small dark brown points or blotches restricted to rays. Adipose fin spine brown. Adipose fin hyaline, sometimes with spot in membrane. Anal fin with spots or blotches in middle zone, sometimes forming one or two short, irregular and oblique strips. Pectoral fin with small dark brown points or blotches restricted to rays with disposition and size similar to dorsal fin. Iris dark grey or black.

Color in formol. Ground color of head grey or dark brown. Opercular reddish grey or brown. Preopercular edge yellowish. Ventral region of head yellowish white. Barbel sometimes with very small blotches.

Ground color of trunk brown with small dark blotches distributed in flank and dorsal area. Large dark blotches over lateral line region on body plates sometimes grouped forming a wide discontinuous and irregular strip. Dorsal region present three great dark blotches slightly distinguished from ground color; first blotch occupies the base of the dorsal fin first rays, second blotch appears at the posterior end of the dorsal fin; and third blotch in adipose fin base. Ventral surfaces of body yellowish white. Dorsal fin hyaline with dark anterior margin and points or small blotches to rays, sometimes forming one or two incomplete oblique strips. Caudal fin with four or five series of small dark brown blotches restricted to rays, forming poorly defined vertical stripe pattern. Caudal fin membranes hyaline. Pelvic fin generally hyaline, eventually with small dark brown points or blotches restricted to rays. Adipose fin spine brown. Adipose fin hyaline, sometimes with spot in membrane. Anal fin with spots or blotches in middle zone, sometimes forming one or two short, irregular and oblique strips. Pectoral fin with small dark brown points or blotches restricted to rays with disposition and size similar to dorsal fin. Iris dark grey or black.

Distribution, biology and ecology data. Currently, this species is only known from 


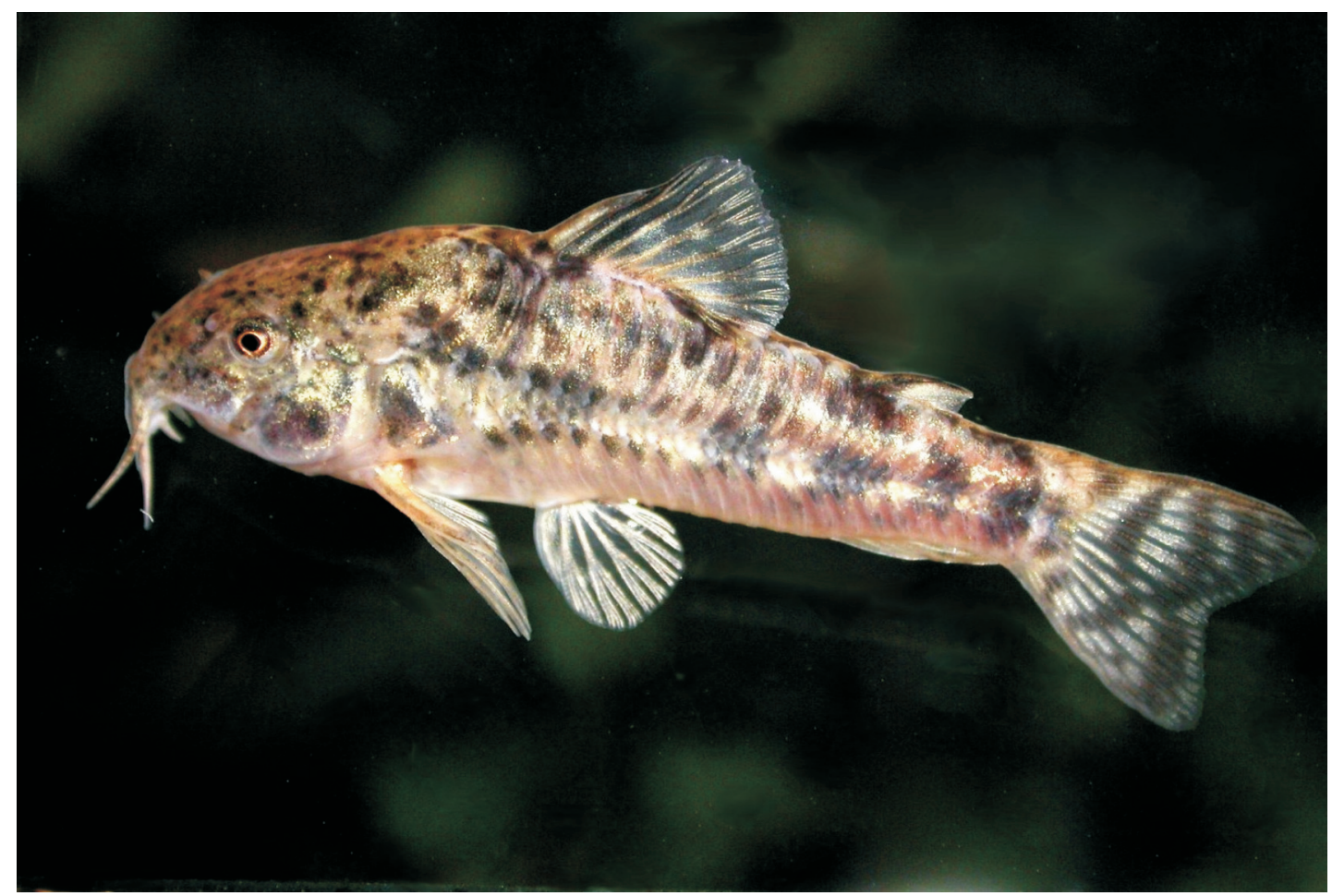

Fig. 2. Corydoras petracinii sp. n., MACN 9233, live holotype, $36.0 \mathrm{~mm}$ SL. Argentina, Salta province, San Lorenzo river (S $24^{\circ} 47^{\prime} 08^{\prime \prime}$ - W 65 28' 10'). Photo: P. Calviño.

Calchaquí river, in the sub-Andean range system, at Cachi and Payogasta localities, in Cachi Department, Salta, Argentina (Fig. 6). This river is a tributary to the superior river basin of the Juramento river, that ends in Paraná river. According to Gonzo (2003), the Calchaquí river is the main collector of the Calchaquíes Valleys. This river and its tributaries conform a dendritic network of Atlantic drainage with a surface estimated at $14.175 \mathrm{~km}^{2}$ and a perimeter of $640 \mathrm{~km}$. Its layout fits into the disposition of mountainous cords and crosses intermountainous valleys of southern course. This river begins at the Nevado del Acay, at 5716 m.a.s.l., where it reaches its maximum height. Its length is 252 kilometers. The drainage network has a remarkable contrast between the East and west the latter with a greater number of affluents of permanent regime, oriented from West to East, and whose volumes are fed by defrosting water (Gonzo, 2003). The diversity of fish of this river is scarce, but most of them are endemic species, of limited distribution, sometimes only in certain sections of the water curse.

Corydoras gladysae was a very rare species in the samplings made and requires a great fishing effort to capture it. The more abundant sympatric species are: Bryconamericus rubropictus (Berg, 1901), Ixinandria steinbachi (Regan, 1906), Heptapterus mustelinus (Valenciennes, 1840), Jenynsia maculata Regan, 1906 and Trichomycterus spegazzinii (Berg, 1897). It is important to remark the permanent presence in this river of an introduced species, the «rainbow trout»: Onchorhyncus mykiss (Walbaum, 1792); this is an active predator that includes small fish in its diet, a reason why it could be affecting the endemic fish populations at the area.

The water from the Calchaquí river at Cachi and Payogasta has a high salinity due to the contribution of tributaries, as well as alkalinity, the $\mathrm{pH}$ measured at Payogasta during the month of August was 8.04. Although aquatic vegetation was not observed in the main channel of this river, the margins as well as secondary branches and adjacent drains show aquatic plants and filamentous algae. Gramineae family plants predominate along the borders and a species of this family was even observed growing totally submerged in one of the places where Corydoras gladysae was found.

Etymology. This species is dedicated to its first collector Gladys Ana María Monasterio de 
Gonzo, Argentine ichthyologist of the Universidad Nacional de Salta (UNSa), who for more than 20 years has been contributing to the knowledge of the diversity, distribution and biology of fishes in the Salta province, Argentina.

Aquariological observations. It is a species that lives in a fast-current river, and in the aquarium it does not swim in open waters. It is not as elegant as other species of the genus and its caudal fin is rarely displayed unfolded. It is usually seen staying in holes between stones. Accepts small worms like tubifex and dried food that reach the aquaria bottom in small amounts.

\section{Corydoras petracinii sp. nov.} (Fig. 2)

Holotype. MACN 9233, $36.0 \mathrm{~mm}$ SL; small stream $200 \mathrm{~m}$ from its ending into the San Lorenzo river (S 24 47' 08' - W 65 28' 10'); Altitude: 1222 m.a.s.l.), Finca Las Costas, around Salta city, Argentina. Coll. F. Alonso and J. Traine, January 2007.

Paratypes. MCNI 1381, 5 specimens, 28.1$38.0 \mathrm{~mm}$ SL; all collected together with the holotype.

Diagnosis. Corydoras petracinii differs from all other species of the genus by the following combination of features: 23 dorsolateral body plates; 21 ventrolateral body plates, small eyes (13.2-17.3\% of HL); body moderately elongate (body depth 27.4-33.1\% SL). Dorsal spine length (19.5-12.6 \% SL); Pectoral spine length $(19,6-$ $16,6 \% \mathrm{SL})$; trunk with 5-7 differentiated subsquare blotches at junction of body plates; caudal fin slightly emarginated, hyaline with joined dark blotches forming 3 or 4 vertical irregular stripe pattern; pectoral, pelvic, and anal fins traslucent without blotches.

Description. Morphometric data is presented in Table 1. Body moderately elongate, robust. Snout rounded, pointless. Head profile convex from the snout to eye; approximately straight from eye to parieto-supraoccipital process. Profile of body straight or slightly convex from tip of parieto-supraoccipital process to last dorsalfin ray. Post-dorsal fin body profile slightly concave to adipose-fin spine; slightly concave from this point to the caudal-fin base. Ventral profile of body slightly convex from isthmus to anal-fin origin. Profile concave from first anal-fin ray to caudal-fin base. Body roughly cylindrical in cross section at pectoral girdle, gradually becoming more compressed toward caudal fin; maximum body width located in humeral region.

Eye round, small for the genus, located dorsolaterally on head; orbit delimited dorsally by frontal and sphenotic, ventrally by infraorbitals; Anterior and posterior nares very close to each other. Anterior naris tubular. Posterior naris non tubular, very close to the orbit anterior margin, separated only by a thin skin. Mouth located ventrally. Maxillary barbel generally not reach anteroventral limit of gill opening. Mental barbel very short. Supraoccipital process externally visible and predorsal plate exposed just in front of first dorsal-fin ray. Posterior expansion of supraoccipital process triangular and elongated, separated from nuchal plate by minimum space. Trunk and head covered by a thin skin, with dispersed tiny odontodes.

Dorsal fin approximately triangular; its origin just on third or fourth dorsolateral body plate. Dorsal spine shorter than first five dorsal fin rays; the third and fourth rays the longest. Dorsal fin rays I,8; Adipose fin short with curved spine, approximately triangular shape; the base of membrane extend over two or three dorsolateral body plates, its origin separated form base of last dorsal-fin by seven to nine dorsolateral body plates. Anal fin approximately triangular with rounded posterior side; its origin (drawing vertical line perpendicular to antero-posterior axis) slightly anterior to origin of adipose fin in most specimens, sometimes it is at the same distance. Anal-fin rays: ii, $5^{*}(1)$. Pectoral fin approximately ovoid; its origin located just posterior to gill opening; distal extreme of pectoral fin overpass the origin of pelvic fin in adults. Ossified portion of pectoral spine shorter than first five branched rays. Pectoral-fin rays: I, 7, or I,8. Pelvic fin ellipsoid; its origin just below third ventrolateral body plates, at vertical through base of second or third dorsal-fin branched ray; it does not reach anal fin base. Pelvic fin base ends just anterior to anus. Pelvic-fin rays: i, $5^{*}(1)$. Caudal fin slightly emarginated. Principal caudal-fin rays $14 *(1)$; upper caudal fin procurrent rays: iii; lower caudal fin procurrent rays: iii.

Dorsolateral body plates: $22 *(1)$ or $23(5)$; ventrolateral body plates: $20 *(1)$ or $21(2)$; dorsolateral body plates on the dorsal fin base: 4(1), $5(3), 6 *(2)$; dorsolateral body plates from adipose fin to caudal fin: $2(1), 3(2), 4^{*}(2)$.

Color in life. Ground color of head brown. Opercle dark brown with golden green reflections. Preopercular edge light brown to reddish. Ventral region of head light. Dark brown irregular blotch between opercle and parieto-su- 


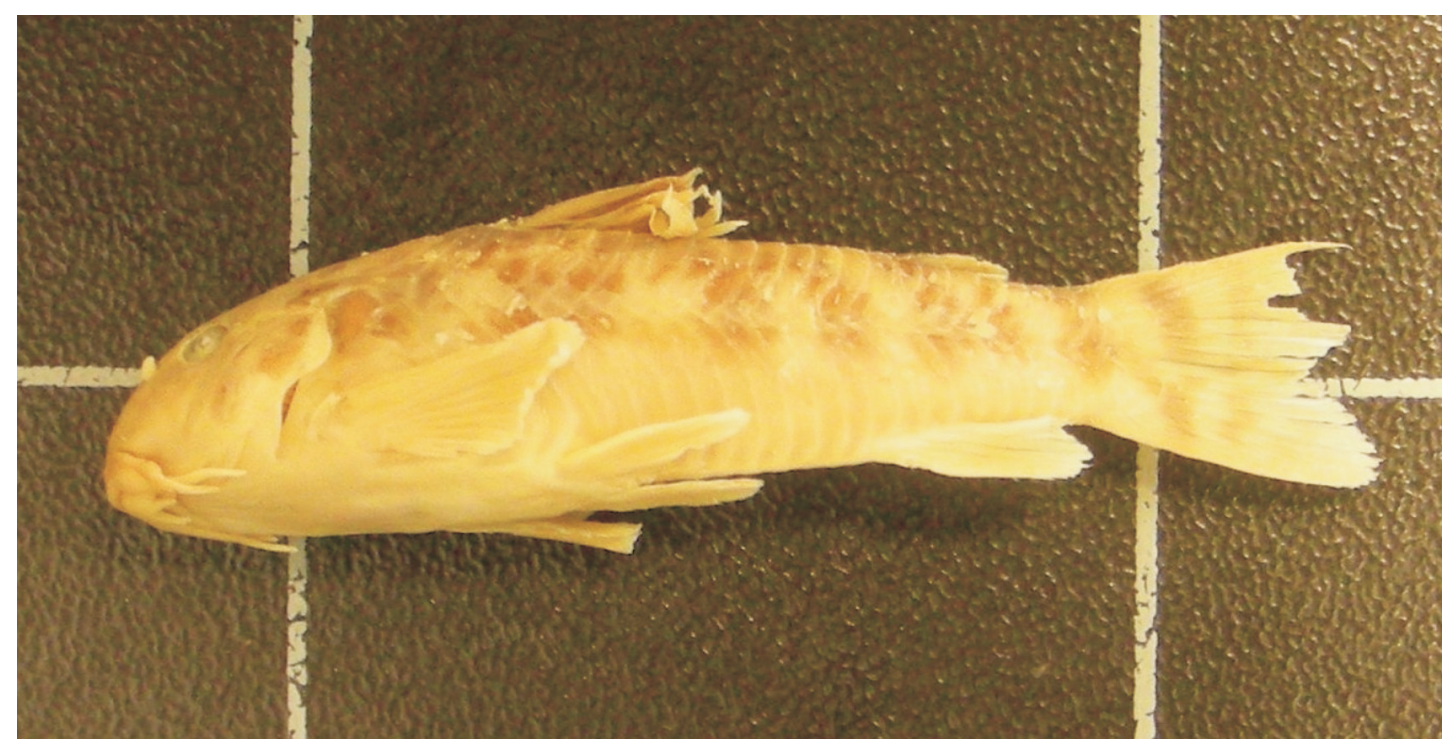

Fig. 3. Corydoras micracanthus, BMNH 1897.1.27.9-14, paralectotype, 38.1 mm LE; Argentina, Salta province. Photo: P. Campbell.

praoccipital process. Barbel yellowish or light brown.

Ground color of trunk light brown or golden yellow with little darker blotches distributed in flanks and dorsal region. Flanks of trunk present in middle region 5 to 7 subsquare differentiated blotches. Dorsal region presents four dark blotches slightly distinguished form the ground color; first blotch occupies the base of the dorsal fin first rays, second blotch appears at the posterior end of the dorsal fin, third blotch in adipose fin base; and fourth blotch over the caudal peduncle, just before the beginning of the caudal fin. Ventral surfaces of body yellowish white. Dorsal fin with dark anterior margin and little blotches to rays, forming oblique strip. Caudal fin with joined dark blotches forming 3 or 4 vertical irregular stripe pattern. Caudal fin membranes hyaline. Pelvic fins without dots or blotches. Adipose fin hyaline, sometimes with blotch in membrane. Adipose spine with dark brown basal area. Anal fin hyaline, without blotches or dots. Pectoral fins pale yellow or hyaline, occasionally very little spots almost imperceptible. Iris dark grey; peripupilar ring golden orange, pupil black.

Color in formol. Ground color of head grayish dark brown. Opercular zone dark reddish grey. Preopercular edge and ventral zone light grey. Barbel brown get lighter toward the ends.

Ground color of trunk light grayish brown with little darker blotches distributed in flanks and dorsal region. Flanks of trunk present in middle region 5 to 7 subsquare differentiated dark brown blotches. Dorsal region presents four dark blotches slightly distinguished form the ground color; first blotch occupies the base of the dorsal fin first rays, second blotch appears at the posterior end of the dorsal fin, third blotch in adipose fin base; and fourth blotch over the caudal peduncle, just before the beginning of the caudal fin. Ventral surfaces of body yellowish white, sometimes dark centre by transparency of internal organs. Dorsal fin with dark anterior margin and little blotches to rays, forming oblique strip. Caudal fin with joined dark blotches forming 3 or 4 vertical irregular stripe pattern. Caudal fin membranes hyaline. Pelvic fins without dots or blotches. Adipose fin hyaline, sometimes with blotch in membrane. Adipose spine dark grey. Anal fin hyaline, without blotches or dots. Pectoral fins pale yellow or hyaline, occasionally very little spots almost imperceptible. Iris dark grey or black.

Distribution, biology and ecology data. This species has only been found in its type locality, a nameless stream at $200 \mathrm{~m}$ from its ending into the San Lorenzo river (S 244' $8.94^{\prime \prime}$ W $65^{\circ} 28^{\prime} 10.61^{\prime}$ ) (Fig.7). This river is part of the Juramento river basin that belongs to a fluvial network that ends in Paraná river at Santa Fe province. This stream, that begins in the hills known as Lomas de Medeiros, goes south to join the San Lorenzo river. It remains dry in almost 


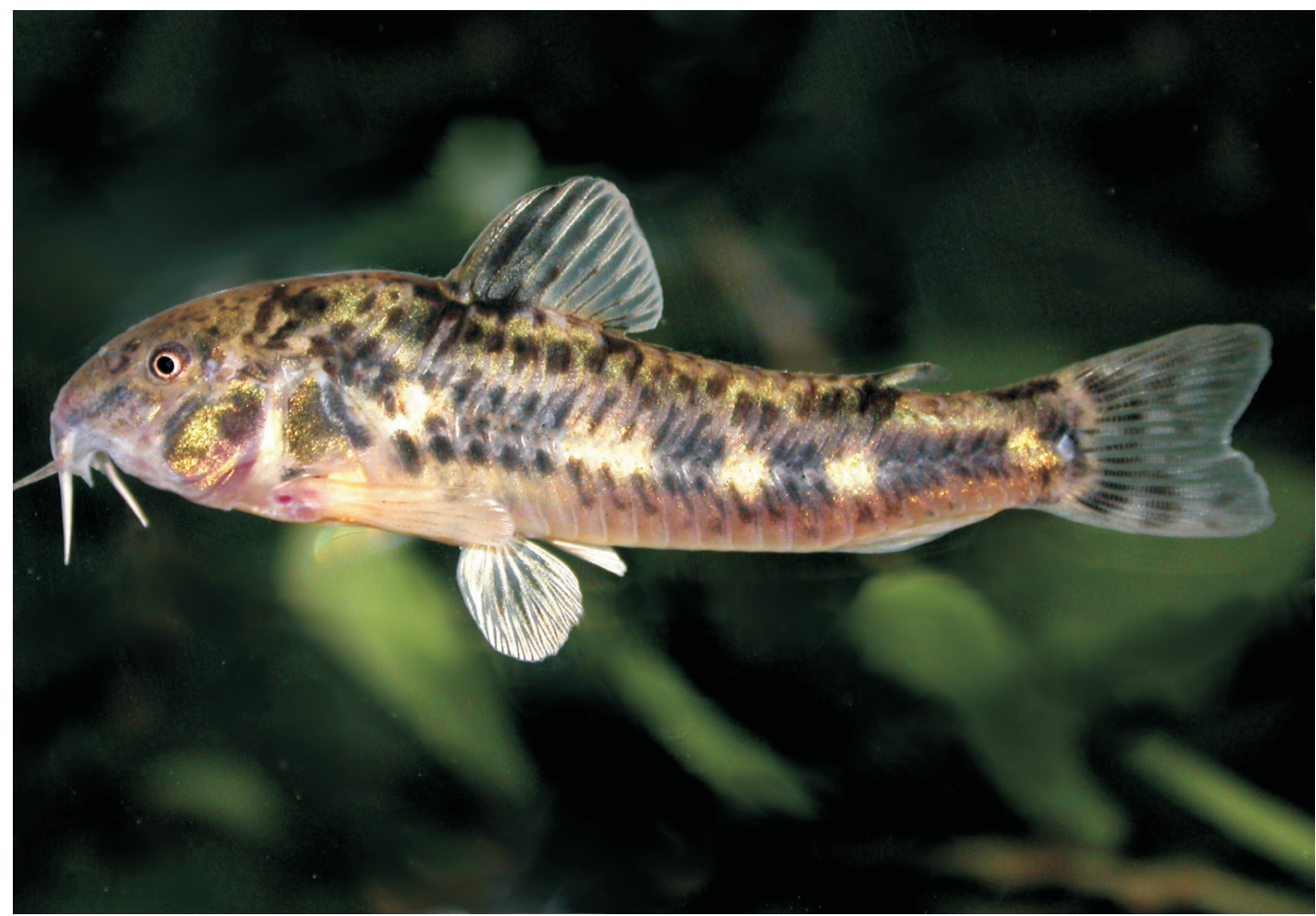

Fig. 4. Corydoras micracanthus, MACN 9234, live topotype, $35.1 \mathrm{~mm}$ SL. Argentina, Salta province, Gallinato creek (S 2440'59" - W 65¹7'32”). Photo: P. Calviño.

all it surface a great part of the year increasing its caudal in the summer, the rainy season. Nevertheless, near its junction in the San Lorenzo river, it has surface water all the year (pers. obs.), probably due to a subterranean water flow from this last river. The Lomas de Medeiros hills were the ancient alluvial cone of Wierna river (Igarzábal \& Medina, 1991).

This species was captured together with Corydoras cf. paleatus, but it is less abundant than this species. Other fish species captured in this habitat were: Hoplias malabaricus (Bloch, 1794); Jenynsia spp.; Heptapterus mustelinus. A great amount of water in the San Lorenzo river at «La Quebrada de San Lorenzo» is used to provide of tap water for the local population which is rapidly increasing. This leads this river to be down stream almost completely dry in winter (dry season), leaving just a few «wells» with water.

Currently there is a highway under construction that passes a few meters alongside this habitat. This situation is destroying it because of the earth extraction from the river and the original water course modification. Also, great amounts of garbage were observed in the surroundings of the rivers. All the alterations of the natural habitat and the proximity of the city together with the poor distribution and frequency of this species puts it and its habitat in a serious danger for its conservation over the long term.

Etymology. The species name is dedicated in honor to Roberto Petracini; Argentine fishkeeper, who for decades has been contributing to the development, knowledge and diffusion of Argentinean and South (and Central) American fishkeeping hobby.

Corydoras micracanthus Regan, 1912 (Figs. 3-4)

Corydoras micracanthus Regan, 1912

Type locality: Salta, Argentina (S $24^{\circ} 46^{\prime}$ - W $\left.65^{\circ} 28^{\prime}\right)$. Lectotype: BMNH 1897.1.27.8, designed by Nijssen \& Isbrücker (1980:206). Paralectotypes: BMNH 1897.1.27.9-14 (6), ZMA 109951 [ex BMNH 1897.1.27.15]

Examined material. BMNH 1897.1.27.9-14, paralectotype, $38.1 \mathrm{~mm} \mathrm{LE}$, (only photographs examined, fig.3); MACN 9234, topotypes, 13 


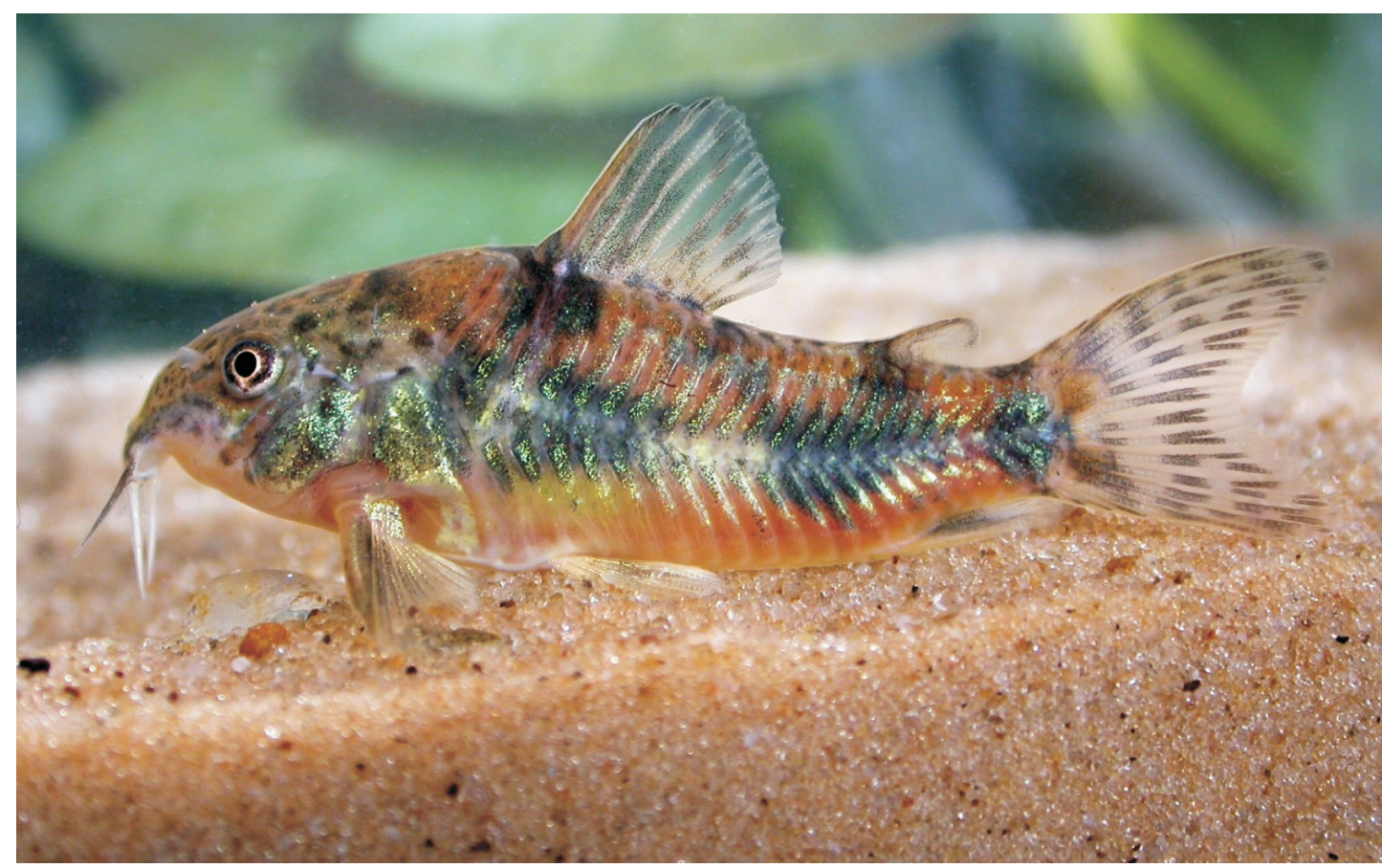

Fig. 5. Corydoras cf. paleatus, MACN 9237, live specimens, $42.0 \mathrm{~mm}$ SL. Argentina, Salta province, small stream 200 meters from its junction with the San Lorenzo river (S $24^{\circ} 47^{\prime} 08^{\prime \prime}$ - W 65²8' 10'). Photo: P. Calviño.

specimens, 29.6-37.0 mm SL, Argentina: Salta province, Lesser river, La Caldera Department, (S 24 $40^{\prime} 39^{\prime \prime}$ - W 65 28' 33'; altitude: 1463 m.a.s.l.). Coll.: P. Calviño \& F. Alonso, January 17, 2006; MACN 9235, 9 specimens, 12.3-35.7 mm SL, same locality as MACN 9234, Col.: F. Alonso, January 2007; MACN 9236, 25 specimens, 27.8-37.9 mm SL, Argentina: Salta province, Gallinato creek, La Caldera Department, (S $24^{\circ} 40^{\prime} 59^{\prime \prime}-\mathrm{W} 65^{\circ} 17^{\prime} 32^{\prime \prime}$; altitude 1159 m.a.s.l.). Col: F. Alonso, January 20, 2006; MCNI 498, 5 specimens, 36.7-40.0 mm SL, Argentina: Salta province, La Caldera river, La Caldera Department. Coll.: Barrros and Rosa, February 5, 1995.

Diagnosis. Corydoras micracanthus is distinguished from all the other species of the genus by the following combination of features: $24-26$ (25) dorsolateral body plates; $21-22$ ventrolateral body plates; small eyes (9.6-16.5 \% of HL); body moderately elongate (body depth 28.1-30.0 \% $\mathrm{SL}$ ); posterior expansion of the parietosupraoccipital process without contacting the predorsal plate; trunk with 4-6 large dark blotches subsquare at junction of body plates; caudal fin slightly emarginated, with joined dark blotches forming 2 or 3 vertical irregular stripe pattern.
C. micracanthus is distinguished from $C$. petracinii by presenting a bigger modal number of dorsolateral body plates ( $25 \mathrm{vs}$. 23): by the shape of the dorsal fin, rounded rectangular (vs. triangular); by the dorsal fin first soft ray not branched in $85 \%$ of individuals examined (vs. always branched in C. petracinii); by the coloration pattern of the trunk flanks that consists on 4-6 large blotches (vs. 5-7 blotches in $C$. petracinii).

Description. Morphometric data is presented in Table 3. Body low and long for the genus. Snout rounded, pointless. Head profile convex from upper-lip to tip of posterior process of parieto-supraoccipital dorsal. Profile of body slightly convex along dorsal-fin base. Postdorsalfin body profile slightly concave to adipose fin spine; concave from this point to caudal-fin base. Ventral profile of body slightly convex from isthmus to anal-fin origin. Profile concave from first anal-fin ray to caudal-fin base. Body roughly cylindrical or ovoid in cross section at pectoral girdle, gradually becoming more compressed toward caudal fin; maximum body width located in humeral region.

Eye round, small for the genus, located dorsolateraly on head; orbit delimited dorsally by frontal and sphenotic, ventrally by infraorbitals. An- 


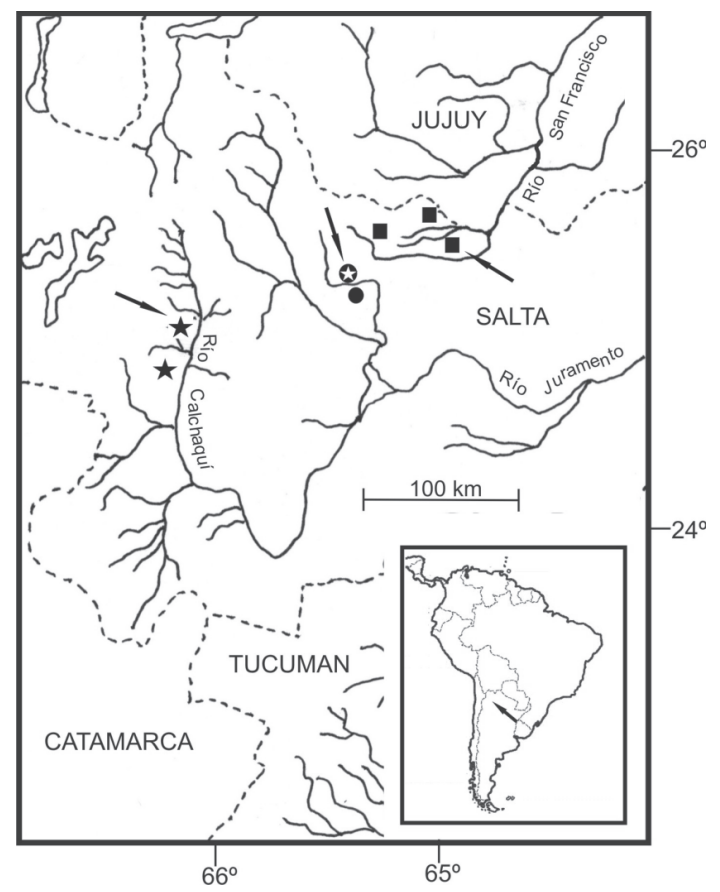

Fig. 6. Geographic distribution of Corydoras micracanthus (squares), C. gladysae (black stars), C. petracinii (white star) and C. cf. paleatus (circle). Arrows = type localities.

terior and posterior nares very close. Anterior naris tubular and posterior naris without tube. Mouth located ventrally. Maxillary barbel generally not reach anteroventral opening of gills; anterior maxillary barbel slightly longer than the posterior maxillary barbel. Mental barbel very short. Small rounded papillae covering entire surface of all barbels, upper and lower lips. Parieto-supraoccipital process externally visible and predorsal plate exposed just in front of first dorsal-fin ray. Supraoccipital process posterior expansion triangular and elongated, separated form predorsal plate by minimum space. Trunk and head covered by a thin skin, with tiny papillae dispersed and odontodes on posterior margin of body plates.

Dorsal fin shape rounded, its origin just over second or third dorsolateral body plate. Dorsal spine shorter than first five dorsal fin rays, posterior border smooth. Dorsal fin rays: I,7-8; the third ray is longest; posterior border of dorsal spine with serrations. Adipose fin approximately triangular; its origin separated from base of last dorsal fin ray by 7-10 dorsolateral body plates (modal $=8)$. Adipose fin preceded by short, curved, well-ossified spine; base of membrane over 2 or 3 dorsolateral body plates. Anal fin approximately triangular with posterior side rounded; its origin (drawing vertical line perpendicular to antero-posterior axis) slightly anterior to adipose fin origin in majority of specimens. Anal fin rays: 7, first half of anal fin first ray is hard. Pectoral fin approximately triangular with its interior margin rounded; its origin just posterior to gill opening. Ossified portion of pectoral spine shorter than first three branched rays; distal extreme of pectoral fin reaches origin of pelvic fins. Pectoral fin rays: I,7 or I,8. Pelvic fin ellipsoid, its origin just under third ventrolateral body plates, at vertical through base of second branched dorsal-fin rays; it not reach anal fin base. Pelvic fin base ends just anterior to anus. Pelvic fin rays: i,5, one specimen i,6. Caudal fin slightly emarginated, upper lobe slightly longer than lower lobe. Principal caudal-fin rays: i,14,i; upper caudal fin procurrent rays: iii; lower caudal fin procurrent rays: iii.

Dorsolateral body plates: 24(1), 25(4), 26(1); ventrolateral body plates: 21 (2) or 22 (6); dorsolateral body plates on the dorsal fin base: 5(7); dorsolateral body plates from adipose fin to caudal fin: 4(1) or 5(6).

Color in life. Ground color of head brown. Opercle dark brown with golden green reflections. Preopercular edge light brown to reddish. Ventral region of head light. Dark brown irregular blotch between opercle and parietosupraoccipital process. Barbel yellowish or light brown.

Ground color of trunk light brown or golden yellow with little darker blotches distributed in flanks and dorsal region. Trunk with 4-6 subsquare differentiated large brown blotches at junction of body plates. Dorsal region presents four dark brown blotches slightly distinguished form the ground color; first blotch occupies the base of the dorsal fin first rays, second blotch appears at the posterior end of the dorsal fin, third blotch in adipose fin base; and fourth blotch over the caudal peduncle, just before the beginning of the caudal fin. Ventral surfaces of body yellowish white. Dorsal fin with dark anterior margin and little blotches to rays, forming oblique strip. Caudal fin with joined dark blotches forming 2 or 3 vertical irregular stripe pattern. Caudal fin membranes hyaline. Pelvic fins without dots or blotches. Adipose fin hyaline, sometimes with blotch in membrane. Adipose spine with dark brown basal area. Anal fin hyaline, without blotches or dots. Pectoral fins pale yellow or hyaline, occasionally very little spots almost imperceptible. Iris dark grey; peripupilar ring golden orange, pupil black. 


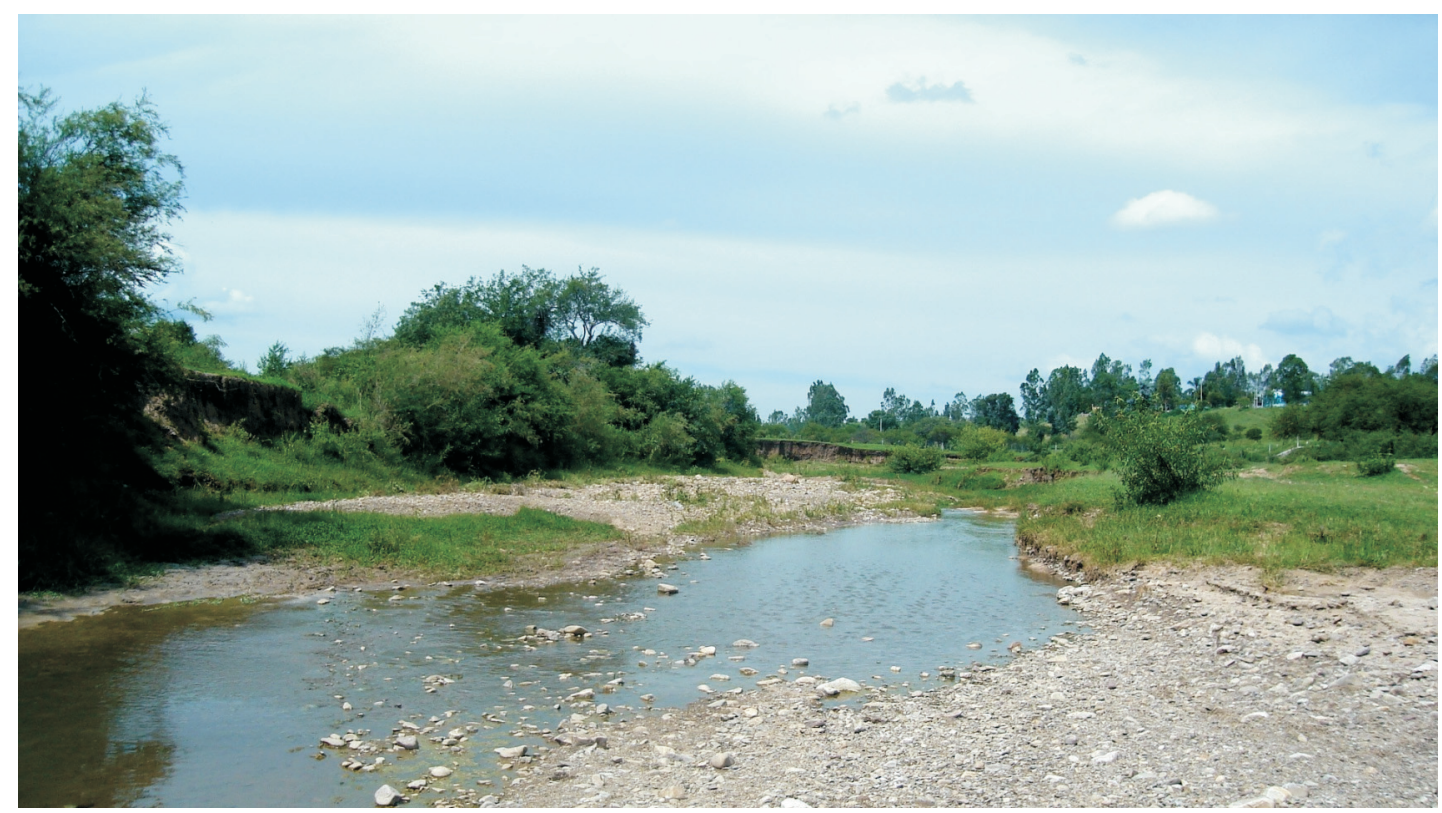

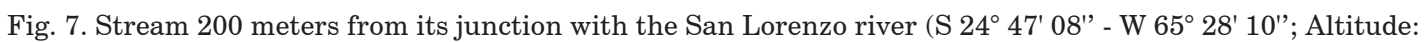
1222 m.a.s.l.), Finca Las Costas, around Salta city, Argentina. Photo: F. Alonso.

Color in formol. Ground color of head grayish brown. Opercle dark brown or reddish grey. Preopercular edge light yellow. Ventral region of head light. Dark brown irregular blotch between opercle and parieto-supraoccipital process. Barbel yellowish or light yellow.

Ground color of trunk light brown or pale yellow with little darker blotches distributed in flanks and dorsal region. Trunk with 4-6 subsquare differentiated large dark blotches at junction of body plates. Dorsal region presents four dark blotches slightly distinguished form the ground color; first blotch occupies the base of the dorsal fin first rays, second blotch appears at the posterior end of the dorsal fin, third blotch in adipose fin base; and fourth blotch over the caudal peduncle, just before the beginning of the caudal fin. Ventral surfaces of body pink white. Dorsal fin with dark anterior margin and little blotches to rays, forming oblique strip. Caudal fin with joined dark blotches forming 2 or 3 vertical irregular stripe pattern. Caudal fin membranes hyaline. Pelvic fins without dots or blotches. Adipose fin hyaline, sometimes with blotch in membrane. Adipose spine with dark brown basal area. Anal fin hyaline or pale yellow, without blotches or dots. Pectoral fins pale yellow or hyaline, occasionally very little spots almost imperceptible. Iris dark grey or black.

Distribution, biology and ecology data. Corydoras micracanthus have only been con- firmed herein in rivers and streams belonging to the Mojotoro river basin, at Gallinato stream (S $\left.24^{\circ} 40^{\prime} 59^{\prime \prime}-\mathrm{W} 65^{\circ} 17^{\prime} 32^{\prime \prime}\right)$, Lesser river (S $24^{\circ} 40^{\prime} 39^{\prime \prime}$ - W $\left.65^{\circ} 28^{\prime} 33^{\prime \prime}\right)$ and La Caldera river, in Salta province, Argentina (Fig. 6).

After checking out the comparative material, the localizations in Gonzo (2003) of Corydoras paleatus for Mojotoro, La Caldera, Lesser and Vaqueros rivers and for Gallinato and Pucheta creeks, Coronel Alfonso Peralta dam (Campo Alegre) and water-drainage channel, would correspond to Corydoras micracanthus and not to C. paleatus.

The Mojotoro river is part of the active basin of the Bermejo river. It includes a dense fluvial network that drains an area of approximately 850 $\mathrm{km}^{2}$, located in the northern region of the «Valle de Lerma». The torrentiality is the main characteristic of these rivers (Igarzábal \& Medina, 1991).

The water at these environments generally has a pH near 7, soft and with low salinity. It is usually very crystalline, with an increase of the caudal and turbidity of the water in the rainy season, in summer, mostly on January and February.

Due to the precipitation regime of the zone, with the dry season on winter, the volume of the rivers and streams fluctuate much throughout the year, with its maximum in the summer, estival period from December to April (Igarzábal \& Medina, 1991). 
TABLE 1. Morphometric data of holotype and paratypes of Corydoras gladysae sp. $n$. SD: standard deviation.

\begin{tabular}{|c|c|c|c|c|c|}
\hline Corydoras gladysae sp. $n$. & Holotype & $\mathrm{N}$ & Range & Mean & $\mathrm{SD}$ \\
\hline Total length (mm) & 45.2 & 9 & $34.3-46.5$ & 42.5 & 4.4 \\
\hline Standard length (mm) & 35.0 & 9 & $27.6-37.5$ & 34.0 & 3.7 \\
\hline \multicolumn{6}{|l|}{ Percents of Standard length } \\
\hline Body depth & 32.7 & 9 & $29.0-35.7$ & 33.0 & 1.9 \\
\hline Body width & 28.1 & 9 & $24.9-28.1$ & 27.0 & 1.2 \\
\hline Predorsal distance & 49.5 & 9 & $41.3-49.5$ & 46.7 & 2.3 \\
\hline Prepelvic distance & 47.2 & 9 & $44.9-51.2$ & 47.7 & 2.1 \\
\hline Preanal distance & 83.6 & 9 & $75.2-83.6$ & 74.2 & 2.4 \\
\hline Preadipose distance & 84.7 & 9 & $77.9-84.7$ & 80.6 & 2.6 \\
\hline Dorsal spine length & 10.6 & 9 & $7.6-10.6$ & 9.2 & 1.1 \\
\hline Longer soft dorsal ray length & 19.7 & 9 & $13.2-21.9$ & 18.1 & 3.2 \\
\hline Pectoral spine length & 15.2 & 9 & $11.9-17.4$ & 14.8 & 1.9 \\
\hline Longer soft pectoral ray length & 20.9 & 9 & $13.0-26.3$ & 18.4 & 4.6 \\
\hline Adipose spine length & 3.7 & 9 & $3.6-8.0$ & 5.2 & 1.6 \\
\hline Caudal peduncle Depth & 15.5 & 9 & $13.33-17.2$ & 14.5 & 1.2 \\
\hline Distance between dorsal and adipose fins & 24.3 & 9 & $17.4-24.3$ & 21.5 & 2.4 \\
\hline Dorsal fin base distance & 19.2 & 9 & $15.2-19.2$ & 17.8 & 1.3 \\
\hline Maximum cleithral width & 16.3 & 9 & $16.3-19.2$ & 17.4 & 1.0 \\
\hline Head length & 41.2 & 9 & $35.7-41.2$ & 37.7 & 1.7 \\
\hline Maxilar barbels length & 10.9 & 9 & $10.9-17.1$ & 15.3 & 1.9 \\
\hline \multicolumn{6}{|l|}{ Percents of Head length } \\
\hline Head depth & 75.0 & 9 & $67.4-81.2$ & 75.2 & 4.3 \\
\hline Head width & 67.4 & 9 & $67.4-75.8$ & 72.0 & 3.3 \\
\hline Least interorbital distance & 36.1 & 9 & $36.0-41.9$ & 38.2 & 2.4 \\
\hline Horizontal orbit diameter & 11.1 & 9 & $7.3-12.5$ & 10.7 & 1.4 \\
\hline Snout length & 50.0 & 9 & $37.5-46.2$ & 42.7 & 3.8 \\
\hline Least internareal distance & 21.5 & 9 & $21.5-36.1$ & 29.3 & 4.1 \\
\hline
\end{tabular}

The aquatic vegetation is less frequent due to the high torrentiality of these ambients, although in water-drains and some streams of low torrentiality the «watercress» and others aquatic plants are abundant together with marginal plants. These environments seem to be favorable to Corydoras micracanthus because they are much more abundant there, which could be due to a greater availability of foods and minor presence of predators like Hoplias malabaricus or catfishes that may be present in bigger water courses, and also this species may be more protected from birds sight by the aquatic plants. The more abundant fish species in these ambients are Jenynsia spp.; Characiformes of small size like Bryconamericus thomasi Fowler, 1940; Trichomycterus spegazzinii; Heptapterus mustelinus; and Ixinandria steinbachi.

\section{DISCUSSION}

The distribution of these three species of Corydoras is restricted to small areas in the Argentinean northwest were they are endemic. C. micracanthus is the one with the major distribution. This group of species is characterized by a short length of the dorsal and pectoral spines, caudal fin slightly emarginated and small eyes for the genus.

The inclusion of these species in the genus Aspidoras Ihering was evaluated at the beginning because they present a short ossified portion of the pectoral and dorsal spines, and a low body height, characteristic features of this genus. However the parieto-supraoccipital bone shape and fontanel corresponds to Corydoras. Also, the genus Aspidoras presents a diagnostic character defined by a foramen in the supraoccipital which is not present in these species. These last features justified the inclusion of these in the genus Corydoras, considering the length of the spines as something more variable, probably due to an adaptation to fast flowing waters. The supraoccipital shape may be an ancestral character with less selective pressure of natural selection. This would make this feature a strong character for the determination of the genus Corydoras. Even though with a more detailed study of the genus Corydoras and a better definition of it, it is probable that some of these species might be placed in new genus. 
TABLE 2. Morphometric data of holotype and paratypes of Corydoras petracinii sp. n. SD: standard deviation.

\begin{tabular}{|c|c|c|c|c|c|}
\hline Corydoras petracinii sp. $n$. & Holotype & $\mathrm{N}$ & Range & Mean & $\mathrm{SD}$ \\
\hline Total length (mm) & 46.0 & 4 & $34.9-46.0$ & 42.3 & 5.0 \\
\hline Standard length (mm) & 36.0 & 6 & $28.1-38.0$ & 33.3 & 4.1 \\
\hline \multicolumn{6}{|l|}{ Percents of Standard length } \\
\hline Body depth & 33.1 & 6 & $27.4-33.1$ & 29.5 & 2.1 \\
\hline Body width & 27.9 & 6 & $23.6-27.9$ & 25.3 & 1.6 \\
\hline Predorsal distance & 46.7 & 6 & $42.4-46.7$ & 44.7 & 1.9 \\
\hline Prepelvic distance & 47.8 & 6 & $43.4-47.9$ & 46.4 & 1.7 \\
\hline Preanal distance & 78.3 & 6 & $74.6-79.21$ & 77.5 & 1.7 \\
\hline Preadipose distance & 78.3 & 6 & $77.6-82.6$ & 80.1 & 1.9 \\
\hline Dorsal spine length & 15.8 & 6 & $12.6-19.6$ & 16.6 & 2.3 \\
\hline Longer soft dorsal ray length & 24.4 & 1 & $24.4-24.4$ & 24.4 & \\
\hline Pectoral spine length & 18.1 & 6 & $16.6-19.6$ & 18.3 & 1.2 \\
\hline Longer soft pectoral ray length & 23.9 & 5 & $23.2-27.4$ & 25.2 & 1.7 \\
\hline Adipose spine length & 8.3 & 6 & 7.6-9.9 & 8.7 & 1.0 \\
\hline Caudal peduncle Depth & 14.4 & 6 & $12.4-15.0$ & 13.6 & 1.0 \\
\hline Distance between dorsal and adipose fins & 20.6 & 6 & $14.6-22.8$ & 19.1 & 3.0 \\
\hline Dorsal fin base distance & 15.6 & 6 & $15.2-22.8$ & 17.8 & 2.7 \\
\hline Maximum cleithral width & 16.7 & 6 & $16.6-21.7$ & 18.7 & 2.3 \\
\hline Head length & 38.6 & 6 & $36.8-42.3$ & 39.2 & 1.8 \\
\hline Maxilar barbels length & 15.0 & 6 & $10.0-19.2$ & 13.7 & 3.5 \\
\hline \multicolumn{6}{|l|}{ Percents of Head length } \\
\hline Head depth & 84.9 & 6 & $70.3-84.9$ & 74.3 & 5.3 \\
\hline Head width & 74.1 & 6 & $63.6-74.1$ & 69.3 & 4.0 \\
\hline Least interorbital distance & 32.4 & 6 & $30.7-33.9$ & 32.0 & 1.3 \\
\hline Horizontal orbit diameter & 13.7 & 6 & $13.2-17.3$ & 14.5 & 1.4 \\
\hline Snout length & 42.5 & 6 & $33.9-42.45$ & 39.0 & 3.1 \\
\hline Least internareal distance & 16.6 & 6 & $14.3-19.0$ & 17.1 & 1.7 \\
\hline
\end{tabular}

In Aspidoras, the posterior process of the supraoccipital is short and separated from the nuchal plate by one to three pairs of dorsolateral body plates. Corydoras and Brochis species, in contrast, typically have the posterior process of the supraoccipital well developed and fully contacting the nuchal plate, with the tips of the bones sometimes overlapping (Britto, 2000).

In Corydoras difluviatilis Britto \& Castro (2002), C. micracanthus and C. gladysae the posterior process of the supraoccipital although well developed, does not contact the nuchal plate, leaving a small gap between these bones, which is covered by fleshy skin. $C$. difluviatilis is distinguished from the species herein denominated the $C$. micracanthus group by a relatively pointed snout (vs. relatively rounded snout).

This absence of contact between supraoccipital and nuchal plate is an ancestral character state for the Callichthyidae family. Considering this and the distribution of the species of the $C$. micracanthus group, plus $C$. difluviatilis, these possibly form a basalmost monophyletic group within the genus Corydoras.
These three species herein denominated the C. micracanthus group live above 1000 m.a.s.l. and had been registered almost up to 2500 m.a.s.l., in the case of C. gladysae. These fish as other benthonic fish of the area such as Ixinandria steinbachi (Loricariidae), has a greenish brown color in the flanks and dorsal regions of body, very similar to the ground color of the detritus and algae that grows over and covers the stones at the bottom. These fish also have dark brown blotches that get confused, when seen, with the shadows generated by the hollows in between the stones (pers. obs.). It has been observed that when these fish feel threatened they quickly look for refuge between the stones and remain steady, which could make them virtually «invisible» to predators such as birds or other fish, making these features a camouflage strategy (crypsis). Cryptic coloration is an antipredative feature (Wickler, 1968; LoweMcConnel, 1987) that allows to these individuals not to give any signals to predators. Axenrot \& Kullander (2003) observed in many Corydoras species that the fish, after an initial evasive reaction to the threat, remain steady. 
TABLE 3. Morphometric data of topotypes of Corydoras micracanthus. SD: standard deviation.

\begin{tabular}{|c|c|c|c|c|}
\hline Corydoras micracanthus, topotypes & $\mathrm{N}$ & Range & Mean & $\mathrm{SD}$ \\
\hline Total length (mm) & 6 & $38.4-48.9$ & 43.6 & 3.7 \\
\hline Standard length (mm) & 6 & $29.6-37.0$ & 33.9 & 2.9 \\
\hline \multicolumn{5}{|l|}{ Percents of Standard length } \\
\hline Body depth & 6 & $28.1-30.0$ & 29.2 & 0.7 \\
\hline Body width & 6 & $23.7-26.2$ & 24.9 & 1.1 \\
\hline Predorsal distance & 6 & $43.8-45.8$ & 44.9 & 0.9 \\
\hline Prepelvic distance & 6 & $42.9-48.1$ & 45.7 & 2.3 \\
\hline Preanal distance & 6 & $70.3-79.3$ & 75.6 & 3.0 \\
\hline Preadipose distance & 6 & $76.5-83.0$ & 80.4 & 2.2 \\
\hline Dorsal spine length & 6 & $11.6-16.6$ & 13.9 & 1.9 \\
\hline Longer soft dorsal ray length & 2 & $18.4-20.7$ & 19.6 & 1.7 \\
\hline Pectoral spine length & 6 & $15.9-18.6$ & 17.3 & 1.0 \\
\hline Longer soft pectoral ray length & 6 & $22.4-28.7$ & 24.2 & 2.3 \\
\hline Adipose spine length & 6 & $6.7-8.5$ & 7.8 & 0.7 \\
\hline Caudal peduncle Depth & 6 & $13.0-15.2$ & 14.1 & 0.7 \\
\hline Distance between dorsal and adipose fins & 6 & $19.8-25.6$ & 22.3 & 2.4 \\
\hline Dorsal fin base distance & 6 & $16.6-19.6$ & 18.0 & 1.3 \\
\hline Maximum cleithral width & 6 & $12.2-16.6$ & 15.2 & 1.6 \\
\hline Head length & 6 & $34.8-38.9$ & 37.5 & 1.4 \\
\hline \multicolumn{5}{|l|}{ Maxilar barbels length } \\
\hline \multicolumn{5}{|l|}{ Percents of Head length } \\
\hline Head depth & 6 & $67.4-73.8$ & 69.8 & 2.2 \\
\hline Head width & 6 & $66.7-75.0$ & 70.4 & 2.9 \\
\hline Least interorbital distance & 6 & $35.6-38.1$ & 36.5 & 1.0 \\
\hline Horizontal orbit diameter & 6 & $9.6-16.5$ & 12.0 & 2.6 \\
\hline Snout length & 6 & $42.4-47.4$ & 44.3 & 2.2 \\
\hline Least internareal distance & 6 & $22.7-27.2$ & 25.7 & 1.7 \\
\hline
\end{tabular}

These fish propel themselves almost exclusively with their tail, not using their pectoral fins as other fish. In fact, the pectoral and dorsal fins have little mobility. The pectoral fins are in a ventral location and slightly rotated, forming an approximate plane parallel to the anteroposterior axis. These fins, together with the dorsal fin have the function of directing and maintaining swimming direction. The pectoral fins also bring more adhesion to the substrate, and help the fish to swim through the bottom in the rapid-flowing water. It has been observed that when these fish swim fast they do it in straight lines and taking sharp curves, generally near the bottom but not in contact with it. When they are feeding they do it slowly, its body inclined with the head pointing towards the bottom exploring with its barbels the substrate looking for food. When they remain steady they usually stand at the bottom on the pectoral and ventral fins, leaving the tail and rest of the body free from the contact with the bottom. This may let them start swimming faster than if they were in contact with the body ventral side on contact with the bottom.

The short length of the fish's spines and the low body height are probably an evolutive con- vergence related with the great torrentiality of the environments where they live. This is supported because even though these species have these features in common they do not seem to be so closely related when you examine other features such as, i.e., the quantity of the lateral plates in C. micracanthus vs. C. gladysae. Also the caudal fin, slightly emarginated, is a typical feature of the species that need a strong propulsion and are not constantly swimming. This hypothesis is also supported because the species with more reduced spines live in the faster flowing rivers.

Corydoras gladysae was previously cited by Gonzo (2003) as Corydoras micracanthus (non Regan, 1912) although C. gladysae differs from C. micracanthus by a less amount of dorsolateral body plates (23 vs. 25), a shorter dorsal spine (media: $9.2 \%$ SL vs. $13.9 \%$ SL), approximately straight dorsal profile of the head from the eye to the parieto-supraoccipital process (vs. convex dorsal profile of the head in C. micracanthus), by the presence of dots or dark brown blotches in the pectoral, pelvic and anal fin (vs. absence of dots or blotches in the pectoral, anal and pelvic fins in C. micracanthus) and by the brown 
ground color of the body with small dark blotches in the flanks and dorsal region (vs. four to six big subsquare blotches in the middle area of flanks in C. micracanthus).

The type locality of $C$. micracanthus is in the Salta province region. Regan (1912) did not specify any river or a more precise localization. C. paleatus is cited from Salta province by several authors (Gonzo et al., 1998; Barros et al., 2001; Nieva et al., 2001; Gonzo 2003). Only Corydoras specimens from Las Costas and Arenales rivers from Salta were determined as Corydoras cf. paleatus (Fig. 5).

Corydoras gladysae clearly differs from $C$. paleatus by a shorter dorsal spine (media: $9.2 \%$ SL vs. $27.1 \%$ SL), by shorter pectoral spines (media 14.8 SL vs. 27.0\% SL) that do not reach the pelvic fins (vs. widely overpass the pelvic fin origin), by the diameter of the eyes, much smaller in relation to the head length (media 10.7 SL vs. $21.9 \%$ SL), by the caudal fin shape, slightly emarginated in C. gladysae (vs. caudal fin notably emarginated in C. paleatus), by the presence of dots or small brown blotches in the pectoral, pelvic and anal fins (vs. notable grey blotches in the pectoral, pelvic, and anal fin in C. paleatus) and by the different body color pattern.

Corydoras petracinii differs from C. gladysae by presenting a longer dorsal spine (12.6-19.6\% SL vs. 7.6-10.6 \% SL, respectively); longer pectoral fin (16.6-19.6 vs. 11.9-17.4\% SL, respectively); caudal fin shape a bit more emarginated (vs. slightly emarginated); by the triangular shape of the dorsal fin (vs. rounded) and by the body flanks and caudal fin color pattern. Corydoras petracinii is distinguished from $C$. micracanthus by presenting a lower modal number of dorsolateral body plates (23 vs. 25); by the triangular dorsal fin shape (vs. rounded rectangular); by the dorsal fin first soft ray branched (vs. not always branched in C. $\mathrm{mi}$ cracanthus), and by the body flanks color pattern with 5-7 small diffuse dark blotches (vs. 46 big blotches in C. micracanthus). C. petracinii could be confused with $C$. paleatus females, and especially with Corydoras cf. paleatus that lived in sympatry with C. micracanthus. Nevertheless, C. petracinii clearly differs by the slightly emarginated caudal fin (vs. notably emarginated in C. paleatus); by the color pattern of the pectoral, pelvic and anal fin, transparent without blotches (vs. presence of dark blotches in $C$. paleatus), by the lower body height (27.3-30.4 vs . $29.9-34.7 \%$ SL) and by the supraoccipital process without contact with the predorsal plate (vs. in contact or overlapped in C. paleatus).

\section{ACKNOWLEDGEMENTS}

To Lucas Hoops for the style and grammar revision of the manuscript; Patrick Campbell (BMNH) kindly provided photographs from the one paralectotype of Corydoras micracanthus deposited at that institution. We are indebted to Roberto Reis, Marcelo Britto and others two anonymous reviewers for their pertinent comments and suggestions on the manuscript.

\section{BIBLIOGRAPHY}

Axenrot, T.H \& S.O. Kullander. 2003. Corydoras diphes (Siluriformes: Callichtyidae) and Otocinclus mimulus (Siluriformes: Loricariidae) two new species of catfishes from Paraguay, a case of mimetic association. Ichthyological Exploration of Freshwaters, (14): 249-272.

Baigún, C., G. López, A.A. Dománico, R. Ferriz, S. Sverlij \& R. Delfino. 2002. Presencia de Corydoras paleatus (Jenyns, 1842), una nueva especie brasílica en el norte de la Patagonia (río Limay) y consideraciones ecológicas acerca de su distribución. Ecología Austral, (12): 41-48.

Barros, S.E., G.M. de Gonzo, \& M. Mosqueira. 2001. Ecología trófica de peces en un río mesoeutrófico en el noroeste de Argentina. Boletín de la Sociedad de Biología de Concepción, Chile, (72): 7-23.

Berg, C. 1897. Contribuciones al conocimiento de los peces Sudamericanos, especialmente de los de la República Argentina. Anales del Museo Nacional de Buenos Aires, (5): 263-302.

1901. Comunicaciones ictiológicas. IV. Comunicaciones del Museo Nacional de Buenos Aires, 1 (9): 293-311.

Bloch, M.E. 1794. Naturgeschichte der ausländischen Fische.Berlin, (8): 1-174.

Britto, M.R. 2000. Aspidoras depinnai (Siluriformes: Callichthyidae), a new species from northeastern Brazil. Copeia, 2000, (4): 1048-1055.

Britto, M.R. \& R.M.C. Castro. 2002. New Corydoradine Catfish (Siluriformes: Callichthyidae) from the Upper Paraná and São Francisco: the sister group of Brochis and most of Corydoras species. Copeia, pp. 1006-1015.

Britto, M.R. \&. F.C.T. Lima. 2003. Corydoras tukano, a new species of corydoradine catfish from the rio Tiquié, upper rio Negro basin, Brazil (Ostariophysi: Siluriformes: Callichthyidae). Neotropical Ichthyology, v. 1 ( 2): 83-91.

Burgess, W.E. \& J. Quinn. 1992. Colored Atlas of Miniature catfish: every species of Corydoras, Brochis, and Aspidoras. Tropical Fish Hobbyst Publications. Inc., Neptune City, New Jersey, 215 pp.

Eigenmann, C.H. \& R.S. Eigenmann.1888. Preliminary notes on South American Nematognathi. I. Proceedings of the California Academy of Sciences, 2 (1): 119-172.

Eigenmann, C.H. \& C.H. Kennedy. 1903. On a collection of fishes from Paraguay, with a synopsis of the 
American genera of cichlids. Proceedings of the Academy of Natural Sciences, Philadelphia, (55): 497-537.

Fowler, H.W. 1940. Zoological results of the second Bolivian expedition for the Academy of Natural Sciences of Philadelphia, 1936-1937. Part I., The fishes Proceedings of the Academy of Natural Sciences, Philadelphia, (92): 43-103.

Gill, T.N. 1858. Synopsis of the fresh water fishes of the western portion of the island of Trinidad, W. I. Annals of the Lyceum of Natural History, New York, (6) $363-430$.

Gonzo, G.M. de. 2003. Peces de los ríos Bermejo, Juramento y Cuencas Endorreicas de la Provincia de Salta, Museo de Ciencias Naturales y Consejo de Investigación Universidad Nacional de Salta, 243 pp.

Gonzo, G.M de., V. Martínez, R.V. Vera \& D. Santos. 1998.Utilización de los recursos y estructura en gremios de comunidades de peces en los ríos de bajo orden. Boletín de la Sociedad de Biología de Concepción, Chile, (69): 131-140.

Gosline, W.A. 1940. A revision of the neotropical catfishes of the family Callichthyidae. Stanford Ichthyological Bulletin, (2): 1-29.

Igarzabal, A.P. \& A.J. Medina. 1991. La cuenca torrencial del río Mojotoro; su evolución y riesgos derivados. Departamento La Caldera, Provincia de Salta. Revista Instituto de Geología y Minería de la Universidad Nacional de Jujuy, (8): 123-144.

Jenyns, L. 1840-42. Fish. En: The zoology of the voyage of H.M. S. Beagle, under the command of Captain Fitzroy, R. N., during the years 1832 to 1836. London. Part IV, pp 1-169.

Knaack, J. 2007. Beitraege zur Kenntnis der Callichthyidae (Teleostei: Siluriformes). III. Corydoras longipinnis sp. n. ein neuer Panzerwels aus dem río Dulce in Argentinien (Teleostei: Siluriformes: Callichthyidae) Vertebrate Zoology 1286: 57 (1): 3555.

López, H.L.; A.M. Miquelarena \& R.C. Menni. 2003. Lista comentada de los peces continentales de la Argentina. ProBiota, FCNyM-UNLP, La Plata, Serie Técnica y Didáctica (5): 1-85.

Lowe-Mc.Connell. R. 1987. Ecological studies in tropical fish communities. Cambridge University Press: $382 \mathrm{pp}$.

Nieva, L.B., R.V. Mesones \& S.E. Ferreira. 2001. Variación estacional en la composición de especies de peces en el paraje La Cineaga, río Arias, Salta, Argentina. Boletín de la Sociedad de Biología de Concepción, Chile, (72): 83-89.

Nijssen, H. \& I.J.H. Isbrücker. 1980. A review of the genus Corydoras Lacépède, 1803 (Pisces, Siluriformes, Callichthyidae). Bijdragen tot der Dierkunde, (50): 190-220.
1986. Review of the genus Corydoras from Peru and Ecuador (Pisces, Siluriformes, Callichthyidae). Studies on Neotropical Fauna and Environment, (21): 1-68.

- 1983. Sept espèces nouvelles de poissons-chats cuirassés du genre Corydoras Lacepède, 1803, de Guyane française, de Bolivie, d'Argentine, du Surinam et du Brésil (Pisces, Siluriformes, Callichthyidae). Revue Française d' Aquariologie et Herpetologie, 3 (10): 73-82.

Regan, C.T.1906. Notes on some loricariid fishes, with descriptions of two new species. Annals and Magazine of Natural History 7 (17): 94-98.

- 1912. A revision of the South-American siluroid fishes of the genus Corydoras, with a list of the specimens in the British Museum (Natural History). Annals and Magazine of Natural History, 8 (10): 209-220.

Reis, R.E. 1997. Revision of the Neotropical catfish genus Hoplosternum (Ostariophysi, Siluriformes, Callichthyidae), with the description of two new genera. Ichthyological Exploration of Freshwaters, (7): 299-326.

- 1998. Anatomy and phylogenetic analysis of the Neotropical callichthyid catfishes (Ostariophysi, Siluriformes). Zoological Journal of the Linnean Society, (124): 105-168.

Ringuelet, R.A., R.H. Arámburu \& A. Alonso de Arámburu. 1967. Los peces argentinos de agua dulce, Comisión de Investigación Científica de la Gobernación de la Provincia de Buenos Aires, La Plata, 602 pp.

Strauss, R.E. 1985. Evolutionary allometry and variation in body form in the South American catfish genus Corydoras (Callichthyidae). Systematics Zoology, Philadelphia, (34): 381-396.

Valenciennes, A. 1835-1847. Poissons; Catalogue des principales espèces de poissons, rapportées de l'Amérique méridionale. En: A. d'Orbigny, (ed). Voyage dans L'Amérique Méridionale (le Brésil, la République Orientale de l'Uruguay, la République Argentine, la Patagonie, la République du Chili, la République de Bolivia, la République du Pérou), Exécuté Pendant les Années 1826, 1827, 1828, 1829, 1830, 1832 et 1833. Paris: Bertrand et Levrault. 5 (2): $1-11$

Walbaum, J.J. 1792. Petri Artedi sueci genera piscium. In quibus systema totum ichthyologiae proponitur cum classibus, ordinibus, generum characteribus, specierum differentiis, observationibus plurimis. Redactis speciebus 242 ad genera 52. Ichthyologiae, pars III. $123 \mathrm{pp}$.

Wickler, W. 1968. Mimicry in plants and animals. Weidenfeld \& Nicolson, London \& McGraw-Hill, New York, 50 pp. 